\title{
Denitrification Losses from Kentucky Bluegrass Sod
}

\author{
C. F. Mancino,* W. A. Torello, and D. J. Wehner
}

\begin{abstract}
Denitrification may represent an important mechanism in the fate of $\mathbf{N}$ applied to turf. Denitrification losses were directly measured from fertilized 'Baron' Kentucky bluegrass (Poa pratensis L.) sod samples sealed in acrylic chambers using the acetylene inhibition technique. Losses were correlated with soil texture, percent soil saturation (SAT), and temperature. Losses from turf on a Hadley silt loam soil and Hadley silt soil (both coarse-silty, mixed, nonacid, mesic Typic Udifluvents) incubated at $22^{\circ} \mathrm{C}$ did not exceed 0.4 and $0.1 \%$, respectively, of the applied potassium nitrate fertilizer $(4.5 \mathrm{~g}$ $\mathrm{N} \mathrm{m}^{-2}$ ) when soil water levels were less than $75 \%$ saturated. Soil saturation increased denitrification losses from the silt loam and silt soils to 2.2 and $5.4 \%$ of the applied $N$, respectively. The relationship between percent soil saturation and denitrification loss was quadratic and highly significant for both soils. The equations are: milligrams of $\mathrm{N}_{2} \mathrm{O}-\mathrm{N} \mathrm{m}^{-2} 10 \mathrm{~d}^{-1}=1432.50-38.96$ (percent SAT silt soil) + 0.26 (percent silt soil) ${ }^{2}$ or $\mathbf{1 3 0 . 8 0}-\mathbf{5 . 4 0}$ (percent SAT silt loam soil) +0.05 (SAT silt loam soil) ${ }^{2}$. A linear relationship [milligrams of $\mathrm{N}_{2} \mathrm{O} \mathrm{m}^{-2} 10 \mathrm{~d}^{-1}=0.49\left({ }^{\circ} \mathrm{C}\right)-9.70$ ] existed between denitrification losses and soil temperatures between 22 and $30^{\circ} \mathrm{C}$ in the silt soil at $75 \%$ of soil saturation. Soil temperatures of $30^{\circ} \mathrm{C}$ or greater coupled with saturated soil conditions resulted in the greatest losses, equivalent to $\mathbf{4 4 . 6}$ and $\mathbf{9 2 . 6 \%}$ of the applied $\mathrm{N}$ to the silt loam and silt soils, respectively. Denitrification losses did not increase at soil temperatures above $30^{\circ} \mathrm{C}$. These results indicate that denitrification loss from fertilizers applied to turfgrasses may not be a serious problem unless the soils are saturated and at higher soil temperatures.
\end{abstract}

Additional index words: Nitrous oxide, Nitrogen fertilizer, Poa pratensis L., Turfgrass.

$\mathrm{D}$ ENITRIFICATION loss after $\mathrm{N}$ fertilizer applications to field and vegetable crops $(1,5,15,20)$ and grasslands $(4,5,7,12,14,21)$ has been studied extensively. No research data is available concerning denitrification losses from 1 ighly managed turfgrass areas.

Conditions that may promote denitrification losses include light, frequent irrigations $(4,5,12,14)$, fertilizer $\mathrm{N}$ applications $(4,14,21)$, incorporation of organic matter into soils $(4,12)$, and higher soil temperatures $(4,7,10)$. These conditions are found in high-quality turfgrass areas, with the organic matter being contributed by the turfgrass root system. Soil temperatures under closely mowed turf may be high (2).

Denitrification losses from irrigated vegetable crops can be as high as $233 \mathrm{~kg} \mathrm{~N} \mathrm{ha}^{-1} \mathrm{yr}^{-1}$ (52\% of applied $\mathrm{N})(14,15)$. Losses from small grains range from 1 to $19 \mathrm{~kg} \mathrm{~N} \mathrm{ha}^{-1} \mathrm{yr}^{-1}(1,5,20)$. Perennial ryegrass (Lolium

C.F. Mancino, Dep, of Plant Sci., Univ. of Arizona, Tucson, AZ 85721; W.A. Torello, Dep. of Plant and Soil Sci., Univ. of Massachusetts, Amherst, MA 01003; D.J. Wehner, Horticulture Dep., Univ. of Illinois, Urbana, IL 61801. Journal Paper no. 2841 of the Massachusetts Agric. Exp. Stn., Amherst, *Corresponding author. Received 11 May 1987.

Published in Agron. J. 80:148-153(1988). perenne L.) swards may lose from 1 to $29 \mathrm{~kg} \mathrm{~N} \mathrm{ha}^{-1}$ $\mathrm{yr}^{-1}(12,14)$. Losses from the grasses are small despite $\mathrm{N}$ applications as high as $500 \mathrm{~kg} \mathrm{~N} \mathrm{ha}^{-1} \mathrm{yr}^{-1}$ (14). Although peak effluxes from soils under grasses and other crops may be similar in magnitude, the duration is shorter in the presence of grasses due to the grass root system's ability to quickly deplete soil $\mathrm{NO}_{3}^{-}-\mathrm{N}$ levels (14). Turfgrass root systems can be shallow due to light, frequent irrigation and close mowing.

Peak $\mathrm{N}_{2} \mathrm{O}-\mathrm{N}$ effluxes (20-50 $\left.\mathrm{mg} \mathrm{N} \mathrm{m}^{-2} \mathrm{~d}^{-1}\right)$ tend to occur during the first few days after an irrigation or rainfall event $(6,17,18)$. These effluxes are associated with wetter soil conditions (more than $20 \% \mathrm{w} / \mathrm{w}$ ) and higher $\mathrm{NO}_{3}^{-}-\mathrm{N}$ levels (more than $5 \mu \mathrm{g} \mathrm{N}$ per gram of soil) (14). These losses are short lived but can be significant in terms of their contribution to total annual denitrification loss.

Soil water and texture influence the denitrification process by affecting gas exchange and the diffusion of $\mathrm{O}_{2}$ to active microbial sites $(12,17,21)$. Small, frequent irrigations have been found to stimulate denitrification $(6,7,18)$, while larger, more frequent irrigations may not (16). A small water input into a finer textured soil may result in greater denitrification losses than from coarser textured soils $(18,21)$.

Increased soil temperature increases denitrification rates $(3,4,10)$. Many factors, however, influence the quantitative effects of temperature on denitrification rate. These include diversity and availability of soil organic matter, and the selective effects of temperature on different bacterial species and denitrifying populations $(8,9)$. Bremner and Shaw (3) found that maximum soil denitrification rates occurred in vitro at $30^{\circ} \mathrm{C}$ in six soils amended with glucose and $\mathrm{NO}_{3}^{-}-\mathrm{N}$.

The objectives of this study were to determine total denitrification losses from Kentucky bluegrass sod as influenced by soil texture, soil water content (percent saturation), and soil temperature.

\section{MATERIALS AND METHODS}

'Baron' Kentucky bluegrass sod samples ( 30.5 by 30.5 by $7.5 \mathrm{~cm}$ ) from Hadley silt and Hadley silt loam sites (Table 1) were installed into clear acrylic chambers constructed of 1.3-cm-thick clear acrylic, and had internal dimensions of 30.5 by 30.5 by $13.0 \mathrm{~cm}$. Each chamber was airtight when its lid was sealed on using a lithium paste. Five perforated copper tubes were installed into the bottom of each chamber, which permitted the injection of acetylene $\left(\mathrm{C}_{2} \mathrm{H}_{2}\right)$ into the sod soils through a septum-sealed sidearm that extended through the chamber wall. The first and second experiments described in this study were conducted in a growth room while the third experiment was done in growth chambers. 


\section{Effect of Soil Water Content}

The initial soil water content of the silt soil was $91.7 \%$ of soil saturation $(48.4 \%$ water, w/w). Soil water levels were determined gravimetrically. Six sod samples were allowed to air dry until the soil was approximately $50 \%$ saturated. Reagent grade potassium nitrate $\left(\mathrm{KNO}_{3}, 3.02 \mathrm{~g}\right.$ per sample $)$ was dissolved in $1.5 \mathrm{~L}$ of water and applied to each of two samples. Final soil water content of these samples was $100 \%$ of saturation. Six hundred milliliters of water were used to apply the same amount of $\mathrm{KNO}_{3}$ to two more samples, bringing the soil water contents to approximately $75 \%$ of saturation. The remaining two samples were allowed to dry to a soil water content of $37 \%$ of saturation before $400 \mathrm{~mL}$ of water containing $\mathrm{KNO}_{3}$ was applied, yielding a final soil water content of approximately $50 \%$ of soil saturation.

Following $\mathrm{N}$ fertilizer and water applications, the chamber lids were sealed onto each chamber. One hundred milliliters of $\mathrm{C}_{2} \mathrm{H}_{2}$ were injected into each box, giving a final soil $\mathrm{C}_{2} \mathrm{H}_{2}$ concentration of approximately $1 \%(\mathrm{v} / \mathrm{v})$. The chambers remained sealed for $12 \mathrm{~h}$ before headspace gas samples were removed. The chambers were then opened and fresh air was circulated around the sod and through the thatch using a hand-held vacuum cleaner. The chambers were again sealed, injected with $\mathrm{C}_{2} \mathrm{H}_{2}$, and allowed to stand for another $12 \mathrm{~h}$. This process was repeated for $10 \mathrm{~d}$, with 12 -h intervals corresponding to light $\left(19.1 \mathrm{~W} \mathrm{~m}^{-2}\right) /$ dark periods. Soil temperature was maintained at $22^{\circ} \mathrm{C}$.

After sampling, the headspace gas was analyzed for $\mathrm{N}_{2} \mathrm{O}-$ $\mathrm{N}$ content using a Varian Series 2700 moduline gas chromatograph (Varian Associates, Inc., Palo Alto, CA) equipped with an electron capture detector $\left(\mathrm{Ti}^{3} \mathrm{H}\right)$. Nitrous oxide was separated from other gases using a Varian Porapak Q column ( $80 / 100 \mathrm{mesh}, 2 \mathrm{~m}$ by $3.2 \mathrm{~mm}$ ). Column temperature was $75^{\circ} \mathrm{C}$, injector port temperature was $195^{\circ} \mathrm{C}$, and detector temperature was $220^{\circ} \mathrm{C}$. The carrier gas was $\mathrm{N}_{2}$ at a flow rate of $14 \mathrm{~mL} \mathrm{~min}{ }^{-1}$. By utilizing the acetylene-inhibition technique, $\mathrm{N}_{2} \mathrm{O}-\mathrm{N}$ loss represented total denitrification loss (16).

After $10 \mathrm{~d}$ the sod samples were replaced with six fresh samples from the silt soil site. Three additional samples were also used for a total of nine sod samples. Initial soil water content of the sod was $66 \%$ of soil saturation. Potassium nitrate was applied in quantities of water ranging from 400 $\mathrm{mL}$ to $2 \mathrm{~L}$, with treatments varying by $200-\mathrm{mL}$ increments. Final soil water contents ranged from 72 to $106 \%$ of soil saturation.

The above study was repeated with nine sod samples from the silt loam soil site (Table 1). Initial soil water content was $93.5 \%$ of saturation ( $40 \%$ water, w/w). After soil water levels fell to approximately $68 \%$ of soil saturation, seven sod samples received $\mathrm{KNO}_{3}$ (3.02 g per sample) applied in water quantities ranging from 400 to $900 \mathrm{~mL}$. The two remaining sod samples were dried to $45 \%$ of soil saturation and the fertilizer was applied in $500 \mathrm{~mL}$ of water. Final soil water levels ranged from 33 to $101 \%$ of soil saturation. Soil temperature was maintained at $22^{\circ} \mathrm{C}$.

Total denitrification loss was calculated on a daily basis as well as on a 10-d basis. Within each soil type, a stepwise regression analysis was used to test for a significant relationship between total denitrification loss from $\mathrm{KNO}_{3}-\mathrm{N}$ treated sod samples and the level of soil saturation. Controls were not used during this study. Preliminary results had shown that total denitrification loss from nonfertilized sod incubated at $22^{\circ} \mathrm{C}$ was insignificantly low, and often undetectable, even under saturated soil conditions.

\section{Effect of Temperature}

In this study, six sod samples from the silt soil were installed in the acrylic chambers and incubated at $22^{\circ} \mathrm{C}$. Initial soil water content was $66 \%$ of soil saturation. Potassium
Table 1. Characteristics of Hadley silt and Hadley silt loam.

\begin{tabular}{lcc}
\hline & \multicolumn{2}{c}{ Soil type } \\
\cline { 3 - 3 } & Silt & Silt loam \\
\hline Particle size, \% & 6 & \\
Clay & 83 & 4 \\
Silt & 11 & 79 \\
Sand & 5.0 & 17 \\
Organic matter, \% & 10.9 & 3.9 \\
Infiltration rate, cm h-1 & 56.8 & 6.9 \\
Percent of soil saturation at field capacity & 6.35 & 5.79 \\
pH & 6.8 \\
\hline
\end{tabular}

nitrate ( $3.02 \mathrm{~g}$ per sample) was applied to three sod samples in $600 \mathrm{~mL}$ of water while three controls received water only. Controls were used in this study because preliminary work had not been conducted to determine $\mathrm{N}_{2} \mathrm{O}-\mathrm{N}$ losses from unfertilized sod incubated at higher temperatures. Final soil water content was approximately $75 \%$ of soil saturation. Total denitrification loss was calculated for a $10-d$ period. The study was repeated at 26 and $30^{\circ} \mathrm{C}$, and a linear regression analysis was used to determine the relationship between denitrification losses and soil temperature.

\section{Interaction of Soil Water Content and Temperature}

Eight sod samples were collected from the silt loam soil site and installed in the acrylic chambers. Initial soil water content was $87 \%$ of soil saturation. All samples were completely saturated with $2 \mathrm{~L}$ of water, with four samples receiving $\mathrm{KNO}_{3}$. Two fertilized and two unfertilized samples were incubated at a soil temperature of $30^{\circ} \mathrm{C}$, and the remaining four samples were incubated at $35^{\circ} \mathrm{C}$ for $10 \mathrm{~d}$. This experiment was repeated using sod from the silt soil site. Initial soil water content of sod from the silt soil was $79 \%$ of soil saturation.

An analysis of variance was used to test for significant differences between total denitrification losses within each soil.

Denitrification losses from controls, when observed, were subtracted from the losses of the $\mathrm{KNO}_{3}-\mathrm{N}$ treated sod in order to calculate fertilizer- $\mathrm{N}$ loss through the denitrification process.

\section{RESULTS AND DISCUSSION}

\section{Effect of Soil Water Content}

Soil water content had a significant quadratic influence on denitrification loss from sod on both the silt and silt loam soils (Table 2). Total denitrification losses were low when both soils were less than $80 \%$ saturated (Fig. 1) and represented less than 0.1 and $0.4 \%$ of the $4.5 \mathrm{~g} \mathrm{~N} \mathrm{~m}^{-2}$ applied to the silt and silt loam soils, respectively. Regardless of soil type, preliminary results found that no detectable $\mathrm{N}_{2} \mathrm{O}-\mathrm{N}$ losses occurred from unfertilized controls at soil water contents below $80 \%$ soil saturation, while less than $4 \mathrm{mg} \mathrm{N} \mathrm{m}^{-2} 10$ $\mathrm{d}^{-1}$ were lost at $98 \%$ of soil saturation.

Table 2. Regression of percent soil saturation on total denitrification losses $\left(\mathrm{mg} \mathrm{N}_{2} \mathrm{O}-\mathrm{N} \mathrm{m}^{-2} 10 \mathrm{~d}^{-1}\right)$ from Kentucky bluegrass sod after $\mathrm{NO}_{\mathrm{s}}^{-}-\mathrm{N}$ addition $\left(4.5 \mathrm{~g} \mathrm{~N} \mathrm{~m}^{-2}\right)$.

\begin{tabular}{lcccc}
\hline $\begin{array}{l}\text { Soil } \\
\text { type }\end{array}$ & $\begin{array}{c}\text { Dependent } \\
\text { variable }\end{array}$ & $\begin{array}{c}\text { Independent } \\
\text { variablet }\end{array}$ & $R^{2}$ & $\begin{array}{c}F \text {. } \\
\text { test }\end{array}$ \\
\hline Silt & $\mathrm{mg} \mathrm{N}_{2} \mathrm{O}-\mathrm{N} \mathrm{m}^{-2} 10 \mathrm{~d}^{-1}=\begin{array}{c}1432.50-38.96(\mathrm{SAT}) \\
+0.26\left(\mathrm{SAT}^{2}\right)\end{array}$ & 0.94 & $* *$ \\
Silt loam & $\mathrm{mg} \mathrm{N} \mathrm{N}_{2} \mathrm{O}-\mathrm{N} \mathrm{m}^{-2} 10 \mathrm{~d}^{-1}=\begin{array}{c}130.80-5.40(\mathrm{SAT}) \\
+0.05\left(\mathrm{SAT}^{2}\right)\end{array}$ & 0.97 & $* *$ \\
\hline
\end{tabular}

** Regression equation significant at the 0.01 probability level.

$\uparrow \mathrm{SAT}=$ percent soil saturation. 


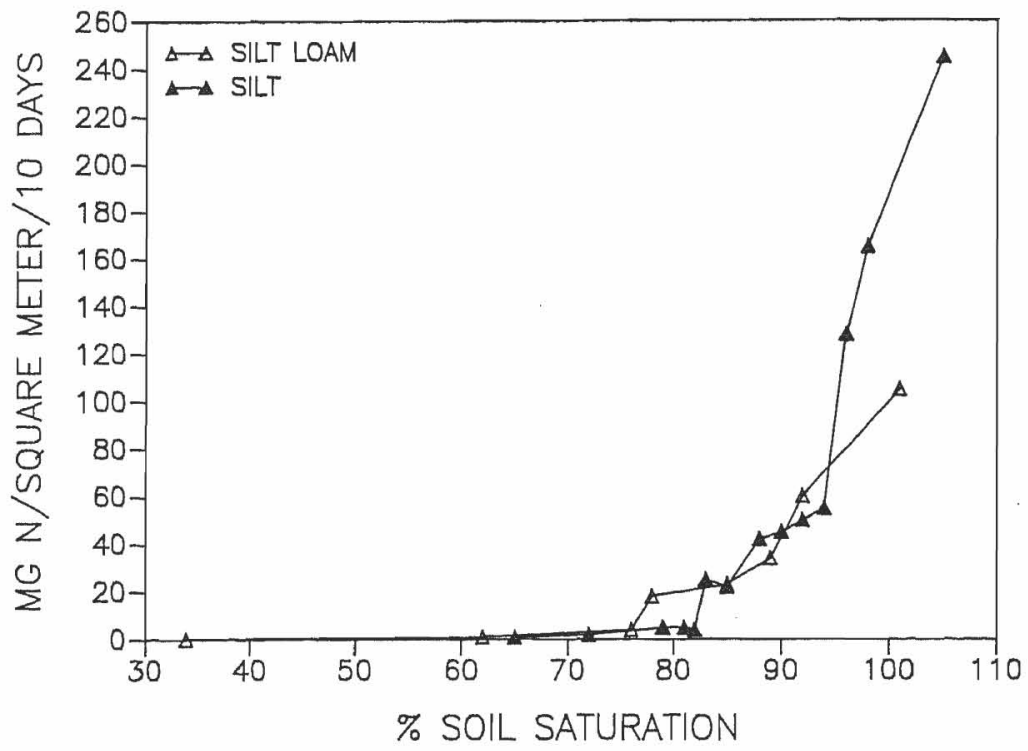

Fig. 1. The influence of soil water content on total denitrification losses from Kentucky bluegrass sod on two soil types incubated at $22^{\circ} \mathrm{C}$ following $\mathrm{KNO}_{3}$ addition $\left(4.5 \mathrm{~g} \mathrm{~N} \mathrm{~m}^{-2}\right)$.

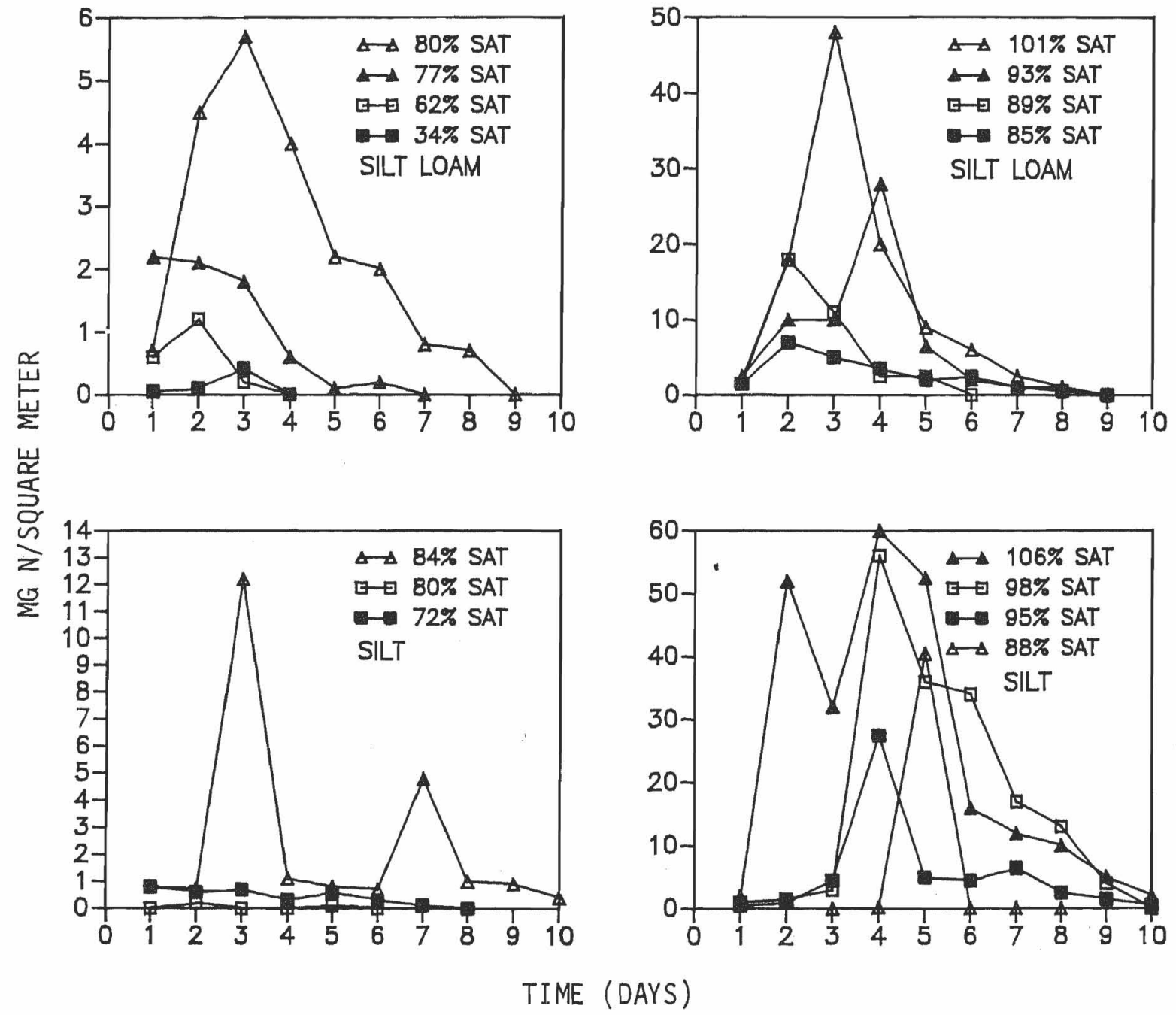

Fig. 2. $\mathrm{N}_{2} \mathrm{O}-\mathrm{N}$ efflux from Kentucky bluegrass sod at $22^{\circ} \mathrm{C}(\mathrm{d} / \mathrm{n})$ at various soil water levels (percent saturation) following $\mathrm{KNO}^{3}$ addition $\left(4.5 \mathrm{~g} \mathrm{~N} \mathrm{~m}^{-2}\right)$. Note differences in scale. 
Table 3. Total denitrification losses from Kentucky bluegrass sod on a silt soil $(75 \%$ saturated) incubated at three soil temperatures after $\mathrm{NO}_{3}^{-}-\mathrm{N}$ addition $\left(4.5 \mathrm{~g} \mathrm{~N} \mathrm{~m}^{-2}\right)$.

\begin{tabular}{ccc}
\hline Soil temperature, ${ }^{\circ} \mathrm{C}$ & $\mathrm{mg} \mathrm{N} \mathrm{O}_{2}-\mathrm{N} \mathrm{m}^{-2} 10 \mathrm{~d}^{-1} \dagger$ & Percent applied N lost \\
\hline 22 & $0.98 \pm 0.17 \ddagger$ & 0.02 \\
26 & $2.93 \pm 0.39$ & 0.07 \\
30 & $4.98 \pm 0.51$ & 0.11 \\
\hline
\end{tabular}

$\dagger \mathrm{mg} \mathrm{N} \mathrm{N}_{2} \mathrm{O}-\mathrm{N} \mathrm{m}^{-2} 10 \mathrm{~d}^{-1}=0.49\left({ }^{\circ} \mathrm{C}\right)-9.70 ; r^{2}=0.99 * *(P=0.01)$. $\ddagger$ Mean of three replications \pm standard error.

Denitrification losses increased when soil water levels were greater than $80 \%$ of saturation (Fig. 1). Maximum losses occurred at saturation and accounted for approximately 5.4 and $2.2 \%$ of $\mathrm{N}$ applied to the silt and silt loam, respectively. These losses are within the range $(0.1-6.6 \%$ of applied $N)$ observed by other researchers working with permanent forage grass swards $(12,14)$. Smith and Tiedje (19) also found denitrifying activity to be greatly increased at soil water levels greater than $75 \%$ of saturation.

Soil texture can influence the extent of denitrification since water movement through a finer textured soil may be impeded resulting in temporary anaerobic soil conditions (21). Sextone et al.(17) reported that greater denitrification losses occurred from a clay loam soil than from a sandy loam soil. Similar results were shown in our study; however, because of the design of the acrylic turf chambers, water drainage was not possible from sod samples. Therefore, the difference in soil water content as affected by a soil's ability to drain was not a variable in this study as it would be in field studies. In addition, soil $\mathrm{NO}_{3}^{-}-\mathrm{N}$ content was similar (50-70 $\mu \mathrm{g} \mathrm{N}$ per gram of soil) for both soils at the time of the completion of the study. Therefore, the larger denitrification losses associated with the silt soil may have been due in part to other soil properties, including $\mathrm{pH}$ and percent organic matter content (Table 1), as well as the silt soil's ability to support larger denitrifying populations (11).
Table 4. Total denitrification losses from Kentucky bluegrass sod on two soil types at $100 \%$ soil saturation and incubated at high soil temperatures after $\mathrm{NO}_{3}^{-}-\mathrm{N}$ addition $\left(4.5 \mathrm{~g} \mathrm{~N} \mathrm{~m}^{-2}\right)$.

\begin{tabular}{ccccc}
\hline $\begin{array}{c}\text { Soil } \\
\text { type }\end{array}$ & $\begin{array}{c}\text { Soil } \\
\text { temperature, }{ }^{\circ} \mathrm{C}\end{array}$ & $\begin{array}{c}\mathrm{mg} \mathrm{N}_{2} \mathrm{O}-\mathrm{N} \\
\mathrm{m}^{-2} 10 \mathrm{~d}^{-1}\end{array}$ & $\begin{array}{c}\text { Percent applied } \\
\text { N lost }\end{array}$ & $F$-test \\
\hline Silt & 30 & $4217 \pm 10 \dagger$ & 94 & NS \\
\multirow{3}{*}{ Silt loam } & 35 & $4102 \pm 32$ & 91 & \\
& 30 & $2037 \pm 13$ & 46 & NS \\
\hline
\end{tabular}

$\uparrow$ Mean of three replications \pm standard error.

$\ddagger \mathrm{NS}=$ nonsignificant at the 0.05 probability level.

Large but short-lived $\mathrm{N}_{2} \mathrm{O}-\mathrm{N}$ emissions have been observed by other researchers $(6,14,17,18)$, with peak emissions as high as 50 and $90 \mathrm{mg} \mathrm{N} \mathrm{m}^{-2} \mathrm{~d}^{-1}$ from perennial ryegrass swards. In our study, peak emissions were as high as 48 and $60 \mathrm{mg} \mathrm{N} \mathrm{m}^{-2} \mathrm{~d}^{-1}$ for the silt loam and silt soils, respectively (Fig. 2). In general, longer periods of $\mathrm{N}_{2} \mathrm{O}-\mathrm{N}$ efflux occurred at soil water levels equal to or greater than $80 \%$ of soil saturation, particularly in the silt soil.

\section{Effect of Temperature}

Soil water levels below $80 \%$ of saturation resulted in denitrification losses that did not vary much as a result of small differences in water content (Fig. 1). As such, a soil water content of approximately $75 \%$ of saturation was selected to examine the influence of soil temperature on denitrification losses. The silt soil was also selected because of its larger denitrification potential, as indicated by total denitrification losses under saturated soil conditions (Fig. 1) and large denitrifier populations (11). The magnitude of $\mathrm{N}_{2} \mathrm{O}-\mathrm{N}$ efflux increased as soil temperature increased from 22 to $30^{\circ} \mathrm{C}$ (Table 3). Total denitrification losses were linearly related (milligrams of $\mathrm{N}_{2} \mathrm{O}-\mathrm{N} \mathrm{m}^{-2} 10 \mathrm{~d}^{-1}=0.49\left({ }^{\circ} \mathrm{C}\right.$ ) - 9.70) to soil temperature. The loss observed from the sod at $22^{\circ} \mathrm{C}$ was in close agreement with the losses observed in the previous study where the silt soil was

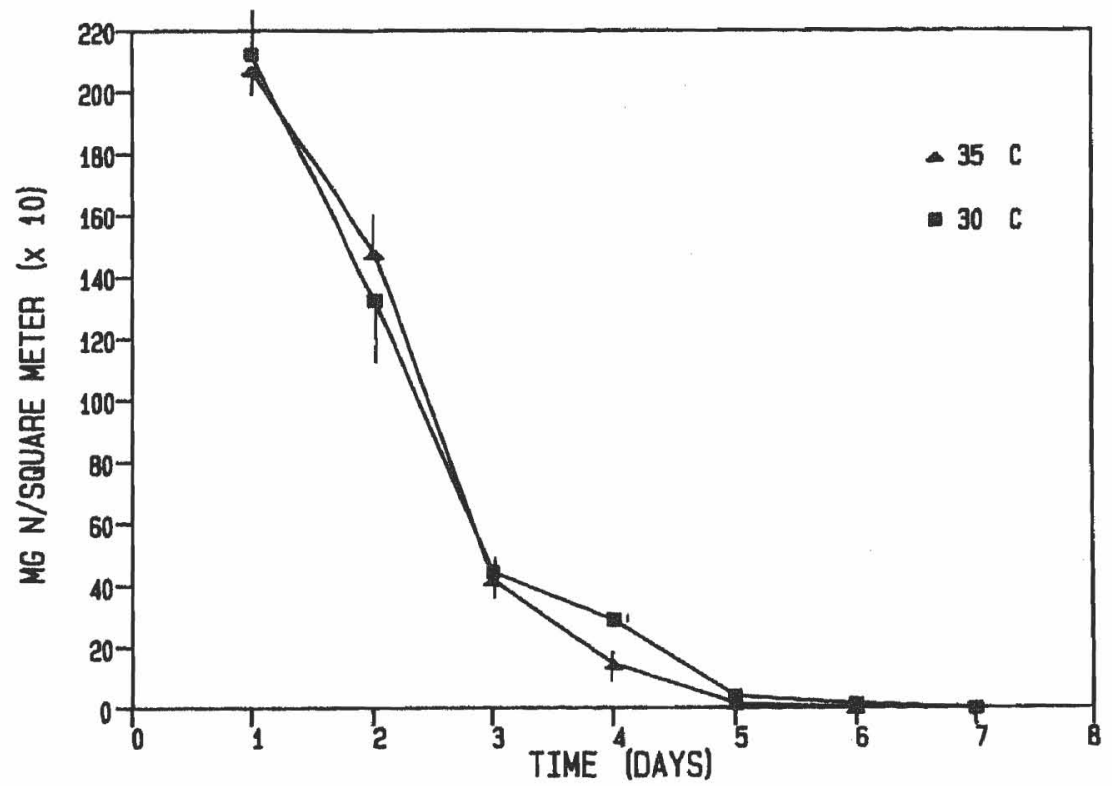

Figure 3. $\mathrm{N}_{2} \mathrm{O}-\mathrm{N}$ efflux from Kentucky bluegrass sod on a saturated silt soil incubated at high soil temperatures following $\mathrm{KNO}_{3}$ addition $\left(4.5 \mathrm{~g} \mathrm{~N} \mathrm{~m}^{-2}\right)$. Vertical lines represent standard error. 


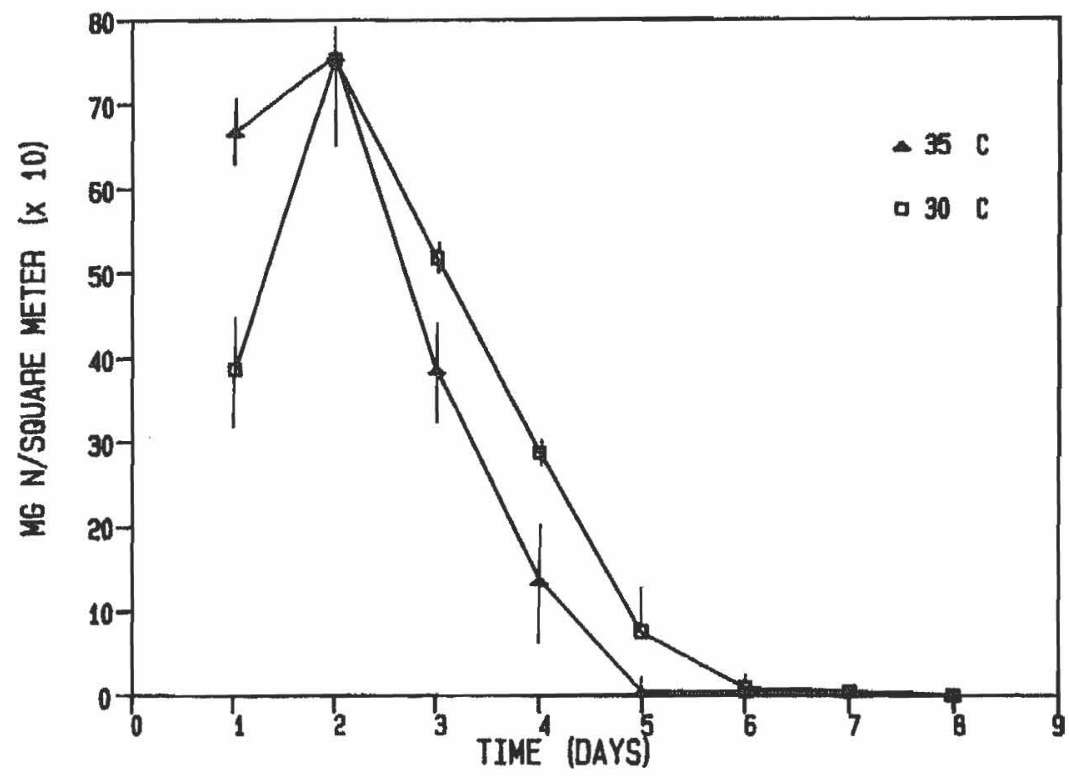

Figure 4. $\mathrm{N}_{2} \mathrm{O}-\mathrm{N}$ efflux from Kentucky bluegrass sod on a saturated silt loam soil incubated at high soil temperatures following $\mathrm{KNO}_{3}$ addition $\left(4.5 \mathrm{~g} \mathrm{~N} \mathrm{~m}^{-2}\right)$. Vertical lines represent standard error.

maintained under similar conditions (Fig. 1). These losses represented less than $0.1 \%$ of the $\mathrm{N}$ fertilizer applied.

\section{Interaction of Soil Water Content and Temperature}

The interaction of increased soil temperatures and saturation resulted in comparatively large denitrification losses from both soils (Table 4). These losses were equivalent to approximately 44.6 and $92.6 \%$ of $\mathrm{N}$ applied to the silt loam and silt soils, respectively.

Greater denitrification losses did not result by increasing the soil temperature from 30 to $35^{\circ} \mathrm{C}$, which may indicate that a maximum denitrification rate occurred at approximately $30^{\circ} \mathrm{C}$. This agrees with the work of Bremner and Shaw (3). Ryden (14) found the largest denitrification losses to occur from a perennial ryegrass sward when soil water levels and temperatures increased in the upper $2.5 \mathrm{~cm}$ of soil. This has also been observed by others working with forage grass swards $(4,13)$.

Saturated turf soil conditions and increased soil temperatures resulted in denitrification losses that were much higher than losses reported by others working with perennial forage grasses $(13,14)$. Peak $\mathrm{N}_{2} \mathrm{O}-\mathrm{N}$ emissions of $2100 \mathrm{mg} \mathrm{N}_{2} \mathrm{O}-\mathrm{N} \mathrm{m}^{-2}$ (Fig. 3) and 750 $\mathrm{mg} \mathrm{N} \mathrm{N}_{2} \mathrm{O}-\mathrm{N} \mathrm{m}^{-2}$ (Fig. 4) from both turf soils are also considered to be extremely high in comparison to peak $\mathrm{N}_{2} \mathrm{O}-\mathrm{N}$ emissions from other fertilized grass swards (4). Ryden (15) did, however, observe a peak flux of $3360 \mathrm{mg} \mathrm{N} \mathrm{m}{ }^{-2}$ from irrigated vegetables.

The results presented in this study represent the first effort to directly measure denitrification losses from $\mathrm{N}$ fertilized turf. In a previous report, we have shown that relatively large populations of denitrifying microorganisms exist in turfgrass soils, indicating a high potential for denitrification (11). Denitrification losses from these turf soils, however, were as low as in other cropped soils, until soil water levels approached saturation. Saturated soil conditions in combination with elevated soil temperatures resulted in very large denitrification losses from fertilized turf. These conditions, in general, do not persist for long periods of time in the field, but this and other research has shown that large denitrification losses may occur quickly and in relatively short time periods.

\section{ACKNOWLEDGMENTS}

Financial support for this research has come from the Department of Plant and Soil Sciences through funding for Experiment Station Project 526 and the O. J. Noer Turf Research Foundation.

\section{REFERENCES}

1. Aulakh, M.S., D.A. Rennie, and E.A. Paul. 1982. Gaseous nitrogen losses from cropped and summer-fallowed soils. Can. J. Soil Sci. 62:187-196.

2. Beard, J.B. 1973. Turfgrass: Science and culture. Prentice-Hall, Inc., Englewood Cliffs, NJ.

3. Bremner, J.M., and K. Shaw. 1958. Denitrification in soil: II. Factors affecting denitrification. J. Agric. Sci. 51:40-52.

4. Christensen, S. 1983. Nitrous oxide emission from a soil under permanent grass: Seasonal and diurnal fluctuations as influenced by manuring and fertilization. Soil Biol. Biochem. 15:531536.

5. Colbourn, P., I.W. Harper, and M.M. Iqbal. 1984. Denitrification losses from is N-labelled calcium nitrate fertilizer in a clay soil in the field. J. Soil Sci. 35:539-547.

6. Denmead, O.T., J.R. Freney, and J.R. Simpson. 1979. Nitrous oxide emission during denitrification in a flooded field. Soil Sci. Soc. Am. J. 43:716-718.

7. Denmead, O.T., J.R. Freney, and J.R. Simpson. 1979. Studies of nitrous oxide emission from a grass sward. Soil Sci. Soc. Am. J. 43:726-728.

8. Focht, D.D. 1978. Methods for analysis of denitrification in soils. p. 433-480. In D.R. Nielsen and J.G. MacDonald (ed.) Nitrogen in the environment. Vol. 2. Academic Press, New York.

9. __ and W. Verstraete. 1977. Biochemical ecology of nitrification and denitrification. p. 135-214. In M. Alexander (ed.) Advances in microbial ecology. Vol. 1. Plenum Press, New York.

10. Jacobson, S.N., and M. Alexander. 1980 . Nitrate loss from soil in relation to temperature, carbon source and denitrifier populations. Soil Biol. Biochem. 12:501-505.

11. Mancino, C.F., and W.A. Torello. 1986. Enumeration of denitrifying microbial populations in turf. Plant Soil 96:145-151.

12. Rolston, D.E., A.N. Sharpley, D.W. Toy, and F.E. Broadbent. 1982. Field measurements of denitrification: III. Rates during irrigation cycles. Soil Sci. Soc. Am. J. 46:289-296. 
13. Ryden, J.C. 1981. Nitrous oxide exchange between a grassland soil and the atmosphere. Nature 292:235-237.

14. 1983. Denitrification loss from a grassland soil in the field receiving different rates of nitrogen as ammonium nitrate. J. Soil Sci. 34:355-565.

15. sured denitrification losses from some irrigated vegetable crop production units. Soil Sci. Soc. Am. J. 44:505-511.

16. $\longrightarrow$, and D.D. Focht. 1979. Direct measurement of denitrification loss from soils: Laboratory evaluation of acetylene inhibition of nitrous oxide reduction. Soil Sci. Soc. Am. J. 43:104-110

17. Sextone, A.J., T.B. Parkin, and J.M. Tiedje. 1985. Temporal response of soil denitrification rates to rainfall and irrigation. Soil Sci. Soc. Am. J. 49:99-103.

18. Smith, C.J., M. Brandon, and W.H. Patrick. 1982. Nitrous oxide emission following urea- $\mathrm{N}$ fertilization of wetland rice. Soil Sci. Plant Nutr. 28:161-171.

19. Smith, M.S., and J.M. Tiedje. 1979. Phases of denitrification following oxygen depletion in soil. Soil Biol. Biochem. 11:261267.

20. Vinther, F.P. 1984. Total denitrification and the ratio between nitrous oxide and $\mathrm{N}_{2}$ during the growth of spring barley. Plant Soil 76:227-232.

21. Webster, C.P., and R.J. Dowdell. 1982. Nitrous oxide emission from permanent grass swards. J. Sci. Food Agric. 33:227-230. 